\title{
DEBATES
}

\section{The rule of law: a challenge for the emerging markets in Mexico and Brazil}

\author{
Estado de direito: o desafio das economias emergentes no México e \\ no Brasil
}

\section{Nubia Nieto}

\begin{abstract}
The new global order has been reshaped in recent times. New actors are emerging from different part of Asia, Latin America and Eastern Europe, even if the president of the United States, Donald Trump, tries to contain this trend. The emerging economies continue their expansion and some analysts predict that they will overtake G7 economies by 2027 . However, the main question raised in this text is not whether the BRIC's countries and emerging countries will surpass developed countries; rather, the emerging countries will be able to create strong institutions and ensure the rule of law, reduce social inequalities and guarantee a sustainable development for a long period, taking advantage of the economic growth that they are living. This text will be focused on analyzing the need to create, maintain, and promote the rule of law in emerging countries, emphasizing the case of Brazil and Mexico, as these countries are in a decisive moment to determine their future.
\end{abstract}

\section{Keywords}

Emerging Markets; BRICs; Rule of Law; Latin America; Global Order.

\section{Resumo}

A nova ordem global foi remodelada nos últimos tempos. Novos atores estáo surgindo de diferentes partes da Ásia, América Latina e Europa Oriental, mesmo que o presidente dos Estados Unidos, Donald Trump, tente conter essa tendência. As economias emergentes continuam a expandir-se e alguns analistas preveem que ultrapassarão as economias do G7 até 2027. No entanto, a principal questão levantada neste texto não é se os países do BRIC e os países emergentes ultrapassarão os países desenvolvidos mas se estes países poderão criar instituiçóes fortes para garantir o Estado de Direito, reduzir as desigualdades sociais e garantir um desenvolvimento sustentável por um longo período, aproveitando o crescimento econômico que estão vivendo. Este texto se concentrará na análise da necessidade de criar, manter e promover o Estado de Direito nos países emergentes, enfatizando o caso do Brasil e do México, pois esses países estáo em um momento decisivo para determinar seu futuro.

\section{Palavras-chave}

Mercados Emergentes; BRICs; Estado de Direito; América Latina; Ordem Global. 


\section{Introduction}

After the collapse of the Soviet Union, the United States was the only superpower in the world, and the only entity capable of deploying military power as well as dictating the economic and political model across the globe. Meanwhile, other countries could flourish from under the shadow of America's power. The power has migrated from the political power to marketplace, from the national to the multinational companies, from unipolar power to multipolar powers (KHANNA, 2009). The new global order has been reshaped in recent times. New actors are emerging from different parts of the planet. Asia, Latin America and East Europe are nowadays more present than ever. Their voices and decisions have consequences for the rest of the world, and their power continues to grow, even if the new U.S. President Donald Trump tries to contain this trend, by considering a $20 \%$ tax on Mexican imports and extending the import taxes to other emerging economies (BEN, 2017).

The emerging economies in 2011 represented nearly 40 percent of the global economy and just 15 percent under of the total value of the world's stock markets (SHARMA, 2012). Some analysts predict that the BRIC ${ }^{1}$ and the emerging markets will overtake $\mathrm{G} 7^{2}$ economies by 2027; other expects that their expansion will shadow the west economies. But the BRICs growth has slowed from almost 9 percent in 2010 to about 4 percent in 2015 due to many factors at external level, among which can be mentioned weak global trade and commodity prices and bouts of financial market turmoil. Internal or domestic factors included slowing productivity growth, rising domestic policy uncertainty and eroding buffers that have constrained the use of accommodative policies (WORLD BANK, 2016). However, the main question raised in this text is not whether the BRIC and the emerging countries will surpass developed countries; rather, if the emerging countries will be able to create strong institutions and ensure the rule of law, reduce social inequalities and guarantee a sustainable development for a long period, taking advantage of the economic growth that they are living. This text will be focused on analyzing the need to create, maintain and promote the rule of law in emerging countries, emphasizing the cases of Brazil and Mexico, as these countries are in a decisive moment to determine their

\footnotetext{
${ }^{1}$ BRIC acronym coined by Jim O'Neill in 2001 to describe the economic growth of Brazil, Russia, India and China (GOLDMAN SACHS, 2003).

${ }^{2}$ G7 is an international finance group comprised by France, United States, United Kingdom, Germany, Canada, Italy and Japan (HAJNAL and MEIKLE, 1999).
} 
future in terms of the human rights of their populations and their position in the current geopolitical landscape.

Since Goldman-Sachs published its first report about BRIC in 2004, in which it considered that BRIC nations would dominate the world economy, a lot of literature regarding emerging ${ }^{3}$ economies or emerging countries has been written. Nevertheless, one of the most important challenges is to analyze to what extent the rule of law ${ }^{4}$ will be able to ensure the rights and access to justice ${ }^{5}$ for the most vulnerable sectors of those countries.

The economic growth of emerging countries is surprising in terms of GDP 6 . According to Magnus, in 2008 world GDP amounted to about $\$ 600,000$ billion, of which $28 \%$ was accounted for by developing countries, half of which originated in the BRIC economies. China, of course, was the biggest single contributor. The

\footnotetext{
${ }^{3}$ The term "emerging" is used in the same sense than Magnus does: "I shall use the term 'emerging' to refer to those countries that show the largest economic potential and that are of interest to investors today, while 'developing' countries comprise the rest or is used as a generic term (...) and emerging markets are defined mostly with reference to their GDP and income per head of population" (MAGNUS, 2011, p. 5-75). Besides, in this text we use the term emerging markets, emerging countries or emerging economies to describe fast economic growth and significant influence on regional and global level.

${ }^{4}$ Following to the definition of the United Nations (UN), the concept of "Rule of law" is defined as "a principle of governance in which all persons, institutions and entities, public and private, including the State itself, are accountable to laws that are promulgated publicly. The laws are applied equally to everybody and they are applied independently. Besides, the laws are adopted in order to ensure the respect of the principles of supremacy of law, equality before law, accountability to law, fairness in the application of law, separation of powers, participation in the adoption of decisions, legality, avoidance of arbitrariness, and transparency legal and procedural" (UN, 2004).

${ }^{5}$ For the Organization of the United Nations, the "justice" is an ideal of responsibility and fairness in the protection and demand of the rights, and the prevention and punishment of the offences. The justice implies taking into account the rights of the accused, the interest of the victims and the welfare of the society as a whole. It is a concept rooted in all cultures and national traditions, despite its administration, which usually implies the existence of judicial mechanisms of official nature, the traditional methods to resolve conflicts are equally relevant. The international community has been working for more than a century to articulate collectively the substantive and procedural requirements of the administration of justice (UN, 2004).

${ }^{6}$ The Gross Domestic Product (GDP) shows how big the current economy is and how fast it's growing. It reports the total estimated value of all goods and services produced in a country (GRIFFIS, 2011).
} 
developing-nation share of world GDP is dominated by Asia, which produces about $40 \%$ of the total, with most of the remainder coming from Latin America, Eastern Europe and Central Asia (MAGNUS, 2011).

Goldman-Sachs (2003) tried to determine which would be the next group of developing countries to follow in the BRICs' wake, and determined the "Next Eleven" or $\mathrm{N}-11^{7}$ to describe the success in their economies. Furthermore, the amazing growth of the emerging markets has also created the acronym MIKT to refer to the largest markets of Mexico, Indonesia, South Korea and Turkey. Other analysts prefer to use the acronym of MINT to describe also the economic success of Mexico, Indonesia, Nigeria and Turkey (O’NEILL, 2011).

\section{The emergence of Brazil and Mexico on the world stage}

Certainly, the classification of the BRICs, N-11, MIKT and MINT is a useful and enduring model to help us understand what is happening in the world's economy and in the new geopolitical landscape. However, this text prefers to use the term emerging markets as a general category to name the largest economic potential in those countries. This article will also focus mainly on describing the cases of Brazil and Mexico as the drive force of the economy in Latin America region. Brazil as a member of the BRIC, and Mexico as member of the N-11 and MIKT and MINT, and both as members of emerging markets, make a significant contribution of the worldwide economy.

For example, Brazil is the world's $7^{\text {th }}$ largest economy with a nominal GDP of 2,254,109 million of US dollars (UN, 2013), the Brazil's GDP overtook Italy's in 2010, making it the seventh largest economy in the world, with a GDP of around $\$ 2.1$ trillion (O’NEILL, 2011). According to the 2050 projections, Brazil has the potential to be much bigger. It has the capacity to become an economy close to $\$ 10$ trillion, about five times bigger than it is today. On a relative basis, Brazil has the potential to overtake Germany and Japan (O’NEILL, 2011).

Meanwhile, Mexico, the world's 14th-largest economy with a nominal GDP of 1,183,655 million of US dollar (UN, 2013), experienced a growth in average income in 2000 of 7 thousand dollars, and 10.6 thousand dollars in 2012 and it is

\footnotetext{
7 The Next Eleven (N-11) are Bangladesh, Egypt, Indonesia, Iran, (South) Korea, Mexico, Nigeria, Pakistan, the Philippines, Turkey and Vietnam. However, O'Neill has also denominated the group of MIKT to refer to the emerging economies of Mexico, Indonesia, South Korea and Turkey, which belong to the N-11. According to O'Neill, Mexico and Korea had the capacity to become almost as important as the BRICs in the global economy (O'NEILL, 2011).
} 
projected to experience a growth in average income in 2050 of 48 thousand dollars (BBC, 2014). According to HSBC bank projections, in six years' time the United States will be more dependent on imports from Mexico than from any other country. Soon "Hecho en Mexico" will become more familiar to Americans than "Made in China" (THE ECONOMIST, 2012). In this context, it is estimated that the GDP in 2050 will be for Brazil 9.71 and for Mexico 6.95, a measure by which both countries will overcome the traditional rich economies of the United Kingdom, which is expected to have a GDP of 5.69, France 5.36 and Germany 5.22 (BBC, 2014).

Furthermore, PWC financial services, one of the most important consulting services in the United Kingdom and Japan, has published a report in which it predicts important changes in the global economy, among them the continuous growth of emerging markets such as Brazil, Russia, India, China, Mexico and Indonesia. The report also affirms that the traditional advanced economies such as the United Kingdom, Germany and France will be overcome by the emerging economies (SOUTHWOOD, 2013). The PWC analysis ranked the top eleven economies most important in the world, the classification is based from 1 to 11 , where 1 is the most important economy and 11 is the less important among the top eleven most important worldwide (SOUTHWOOD, 2013).

The report indicates that in 2011, the first economy worldwide and the most important was the United States, China second, India third, Japan fourth, and the following in decreasing order, Germany, Russia, Brazil, France, United Kingdom, Italy and Mexico (SOUTHWOOD, 2013). By 2030, PWC predicts that the first economy in the world and the most important will be China, then the United States, India, Japan, Russia, Brazil, Germany, Mexico, United Kingdom, France, and Indonesia (SOUTHWOOD, 2013).

\section{The Billionaires from Brazil and Mexico}

According to PWC, the United States will be surpassed by China. Russia and Brazil will overcome Germany. Mexico will overpass the United Kingdom and France. And Indonesia will be in the eleventh place, kicking out Italy of the list of the eleven economies most important worldwide. By 2050, according to PWC forecasts, the first economy most important in the world will be China, the second the United States, the third India, the fourth Brazil, the fifth Japan, the sixth Russia, the seventh 
Mexico, the eighth Indonesia, the ninth Germany, the tenth France and the last one, the eleventh United Kingdom (SOUTHWOOD, 2013).

Following this report, by 2050, China, the United States and India will maintain their positions of 2030. Brazil will eclipse Japan. Russia, and Mexico, and Indonesia will overtake Germany, France and the United Kingdom (SOUTHWOOD, 2013). In line with the above economic forecast, it can be observed that Brazil and Mexico will continue growing worldwide, but the question is how able will be Brazil and Mexico to reduce the social inequalities, especially when there is still a huge concentration of global wealth in the hands of a few.

According to the list of the World's billionaires 2011 published by Forbes, in Mexico there were 11 billionaires with a Total Net Worth (in US billion of dollars) of 125.1, and with a Total Net Worth as per cent Gross Domestic Product (GDP) of 12.5. While in Brazil there were 30 billionaires with Total Net Worth (in US billion of dollars) of 131.4; and with Total Net Worth as per cent Gross Domestic Product (GDP) of 6.5. The same list published by Forbes one year after showed a huge increased of billionaires in Brazil from 30 in 2011 to 79 in 2012 (FORBES, 2012a). And Mexico continued with 11 billionaires (FORBES, 2012b), whose names and fortunes are displayed in the following table:

Table 1 - Mexican Rich List 2012

\begin{tabular}{l|l|l|l}
\hline Rank & Name & Net worth (US Dollars) & Sources of wealth \\
\hline 1 & Carlos Slim & US\$ 74 billion & $\begin{array}{l}\text { Telmex, INBURSA, América Móvil, } \\
\text { CompUSA, WorldCom and Telcel }\end{array}$ \\
\hline 2 & Ricardo Salinas Pliego & US\$ 17.4 billion & TV Azteca, Iusacell, Unefon \\
\hline 3 & Alberto Baillères & US\$ 16.5 billion & Peñoles \\
\hline 4 & $\begin{array}{l}\text { Germán Larrea Mota- } \\
\text { Velasco }\end{array}$ & US\$ 14.2 billion & Grupo Mexico \\
\hline 5 & Jerónimo Arango & US\$ 4 billion & $\begin{array}{l}\text { Founder of Aurrerá (currently part } \\
\text { of Wal-Mart Mexico) }\end{array}$ \\
\hline 6 & Emilio Azcárraga Jean & US\$ 2 billion & $\begin{array}{l}\text { Televisa, Univision, Club América, } \\
\text { Necaxa, Club San Luis }\end{array}$ \\
\hline 7 & Roberto González Barrera & US\$ 1.9 billion & Maseca, Banorte \\
\hline 8 & Carlos Hank Rhon & US\$ 1.4 billion & Bank \\
\hline 9 & $\begin{array}{l}\text { Roberto Hernandez } \\
\text { Ramirez }\end{array}$ & US\$ 1.3 billion & $\begin{array}{l}\text { Banco Nacional de México } \\
\text { (Banamex) }\end{array}$ \\
\hline 10 & Alfredo Harp Helú & US\$ 1 billion & Banamex, Red Devils Baseball Team \\
\hline 11 & Joaquín Guzmán Loera & US\$ 1 billion & Sinaloa Cartel \\
\hline $\begin{array}{l}\text { Source: Forbes. The list of Mexican billionaires based on an annual assessment of wealth and assets, } \\
\text { New York, US: Forbes magazine, March 10, 2012a. }\end{array}$
\end{tabular}


And for the case of Brazil, the list of billionaires is even bigger than in Mexico as can be observed in the following table:

Table 2 - Brazilian Rich List 2012

\begin{tabular}{|c|c|c|c|}
\hline Rank & Name & $\begin{array}{l}\text { Net worth } \\
\text { (US Dollars) }\end{array}$ & Sources of wealth \\
\hline 1 & Jorge Paulo Lemann & 21.7 billion & $\begin{array}{l}\text { Anheuser-Busch InBev, Lojas } \\
\text { Americanas }\end{array}$ \\
\hline 2 & Joseph Safra & 12.1 billion & Safra Group \\
\hline 3 & Marcel Herrmann Telles & 10.1 billion & $\begin{array}{l}\text { Anheuser-Busch InBev, Lojas } \\
\text { Americanas }\end{array}$ \\
\hline 4 & Carlos Alberto Sicupira & 8.8 billion & $\begin{array}{l}\text { Anheuser-Busch InBev, Lojas } \\
\text { Americanas }\end{array}$ \\
\hline 5 & Roberto Irineu Marinho & 7.5 billion & Organizações Globo \\
\hline 6 & João Roberto Marinho & 7.5 billion & Organizaçóes Globo \\
\hline 7 & José Roberto Marinho & 7.5 billion & Organizações Globo \\
\hline 8 & Antonio Ermirio de Moraes & 6.2 billion & Votorantim Group \\
\hline 9 & Ermirio Pereira de Moraes & 6.2 billion & Votorantim Group \\
\hline 10 & Maria Helena de Moraes & 6.2 billion & Votorantim Group \\
\hline 11 & Giancarlo Civita \& family & 4.9 billion & Grupo Abril \\
\hline 12 & Walter Faria & 4.6 billion & Grupo Petrópolis \\
\hline 13 & Norberto Odebrecht \& family & 4.5 billion & Odebrecht \\
\hline 14 & Francisco Ivens de Sá Dias Branco & 4.4 billion & M. Dias Branco \\
\hline 15 & Cesar Mata Pires & 4.3 billion & Grupo OAS \\
\hline 16 & André Esteves & 4.0 billion & BTG Pactual \\
\hline 17 & Aloysio de Andrade Faria & 4.0 billion & Grupo Alfa \\
\hline 18 & Regina de Camargo Pires Oliveira Dias & 3.8 billion & Camargo Corrêa \\
\hline 19 & Renata de Camargo Nascimento & 3.8 billion & Camargo Corrêa \\
\hline 20 & Rosana Camargo de Arruda Botelho & 3.8 billion & Camargo Corrêa \\
\hline 21 & Abilio dos Santos Diniz & 3.7 billion & Grupo Pão de Açúcar \\
\hline 22 & Ana Lucia de Mattos Barretto Villela & 3.6 billion & Itaú Unibanco \\
\hline 23 & Yolanda Vidal Queiroz & 3.6 billion & Grupo Edson Queiroz \\
\hline 24 & Alfredo Egydio Arruda Villela Filho & 3.4 billion & Itaú Unibanco \\
\hline 25 & Antonio Luiz Seabra & 3.2 billion & Natura \\
\hline 26 & Carlos Jereissati & 3.2 billion & Grupo Jereissati \\
\hline 27 & Nevaldo Rocha & 3.0 billion & Grupo Guararapes \\
\hline 28 & Fernando Roberto Moreira Salles & 2.7 billion & Itaú Unibanco \\
\hline
\end{tabular}


16 | Nubia Nieto

\begin{tabular}{|c|c|c|c|}
\hline 29 & João Moreira Salles & 2.7 billion & Itaú Unibanco \\
\hline 30 & Pedro Moreira Salles & 2.7 billion & Itaú Unibanco \\
\hline 31 & Walter Moreira Salles Júnior & 2.7 billion & Itaú Unibanco \\
\hline 32 & Rubens Ometto Silveira Mello & 2.6 billion & Cosan \\
\hline 33 & Miguel Krigsner & 2.7 billion & O Boticário \\
\hline 34 & Edson de Godoy Bueno & 2.6 billion & DASA \\
\hline 35 & $\begin{array}{l}\text { Ana Maria Marcondes Penido } \\
\text { Sant'Anna }\end{array}$ & 2.6 billion & CCR S.A. \\
\hline 36 & Roberto Egydio Setúbal & 2.5 billion & Itaú Unibanco \\
\hline 37 & Ricardo Egydio Setúbal & 2.5 billion & Itaú Unibanco \\
\hline 38 & Dulce Pugliese de Godoy Bueno & 2.4 billion & DASA \\
\hline 39 & Moise Safra & 2.4 billion & Safra Group \\
\hline 40 & Maria de Lourdes Egydio Villela & 2.2 billion & Itaú Unibanco \\
\hline 41 & Eduardo Saverin & 2.2 billion & Facebook \\
\hline 42 & João Alves de Queiroz Filho & 2.1 billion & Hypermarcas \\
\hline 43 & Lirio Parisotto & 2.0 billion & Investor \\
\hline 44 & Carlos Alberto de Oliveira Andrade & 2.1 billion & Grupo Caoa \\
\hline 45 & José Batista Sobrinho \& family & 1.9 billion & JBS S.A. \\
\hline 46 & Adriano Schincariol & 1.9 billion & \\
\hline 47 & Alexandre Schincariol & 1.9 billion & \\
\hline 48 & Samuel e Michael Klein \& family & 1.9 billion & Viavarejo \\
\hline 49 & Elie Horn & 1.9 billion & $\begin{array}{l}\text { Cyrela Brazil Realty, Cyrela } \\
\text { Commercial Properties }\end{array}$ \\
\hline 50 & José Isaac Peres & 1.9 billion & Multiplan \\
\hline 51 & Daisy Igel & 1.8 billion & Ultrapar \\
\hline 52 & Jayme Garfinkel \& family & 1.8 billion & Porto Seguro S.A. \\
\hline 53 & Rubens Menin & 1.7 billion & MRV Engenharia \\
\hline 54 & Guilherme Peirão Leal & 1.8 billion & Natura \\
\hline 55 & Lina Maria Aguiar & 1.6 billion & Bradesco \\
\hline 56 & Victor Gradin \& Family & 1.5 billion & Odebrecht \\
\hline 57 & Julio Bozano & 1.4 billion & Embraer, Grupo Bozano \\
\hline 58 & Eggon João da Silva & 1.4 billion & WEG Industries \\
\hline 59 & Werner Ricardo Voigt & 1.4 billion & WEG Industries \\
\hline 60 & Lilian Werninghaus & 1.4 billion & WEG Industries \\
\hline 61 & Alexandre Bartelle Grendene & 1.4 billion & Grendene, Unicasa \\
\hline 62 & Silvio Santos & 1.3 billion & Grupo Silvio Santos \\
\hline 63 & Lily Safra & 1.2 billion & Inheritance \\
\hline
\end{tabular}




\begin{tabular}{|c|c|c|c|}
\hline 64 & Antonio José Carneiro & 1.2 billion & Energisa \\
\hline 65 & Alfredo Egídio Arruda Villela Filho & 1.2 billion & Itaú Unibanco \\
\hline 66 & Ana Lúcia de Mattos Barretto Villela & 1.2 billion & Itaú Unibanco \\
\hline 67 & Rosa Evanlenina Marcondes Penido & 1.1 billion & CCR S.A. \\
\hline 68 & João Carlos Cavalcanti & 1.1 billion & Global Mining Exploration \\
\hline 69 & Deusmar de Queiroz & 1.1 billion & Pague Menos \\
\hline 70 & Guilherme Paulus & 1.1 billion & Grupo CVC \\
\hline 71 & Edir Macedo & 1.1 billion & Central Record de Comunicaçóes \\
\hline 72 & Dorothea Steinbruch & 1.1 billion & $\begin{array}{l}\text { CSN, Grupo Vicunha, Banco } \\
\text { Fibra }\end{array}$ \\
\hline 73 & Liu Ming Chung & 1.1 billion & $\begin{array}{l}\text { Nine Dragons Paper Holdings } \\
\text { Limited }\end{array}$ \\
\hline 74 & José Janguiê Diniz & 1.1 billion & Ser Educacional \\
\hline 75 & Décio Goldfarb \& family & 1.0 billion & Marisa S.A. \\
\hline 76 & Jorge Gerdau Johannpeter \& family & 1.0 billion & Gerdau \\
\hline 77 & Marcos Antonio Molina & 1.0 billion & Marfrig \\
\hline 78 & Carlos Wizard Martins & 1.0 billion & \\
\hline 79 & Marco Antonio Laffranchi & 1.0 billion & Kroton Educacional \\
\hline
\end{tabular}

Source: Forbes. The list of Brazilian billionaires based on an annual assessment of wealth and assets, New York, US: Forbes magazine, December, 2012b.

Certainly, if a country is generating too many billionaires, yet has a huge population without the minimal conditions of living, there exists a serious imbalance. This is an indication that the country needs to pay attention to reduce inequality among their population, particularly if they have large demographics. In 2010, Mexico accounted for a population of 110.6 millions, as Brazil registered a population of 195.4 millions (MAGNUS, 2011). And in 2012, the Mexican population was estimated in $117,054,000$ persons, while the Brazilian population for the same year reached 196, 526,000 habitants. These figures give an idea of the lack of balance between the rich and the poor, and the challenges coming ahead (OECD, 2014a).

\section{Chalenges and opportunities for Brazilians and Mexicans}

The success of the emerging countries is a positive hope for the world. Nevertheless, the most important thing is to see if that wealth will diminish, alleviate or eliminate the levels of poverty, impunity, and corruption existing in those countries. Along the same line, the Corruption Perceptions Index published by 
Transparency International in 2016, using a scale from 0 to 100 , where 0 means that a country is perceived as highly corrupt and 100 means it is perceived as very clean. The rank is given taking into account a total of 176 countries. In this scale, Brazil reached the rank 79, and scores 40 out 100, while Mexico got the rank 123 with a score of 30 out 100 (TI, 2016). These data give a general picture about the levels of corruption in Mexico and Brazil, and the contradiction between the rule of law and its application on the ground.

The excessive generation of tycoons in some emerging countries, particularly in Brazil and Mexico seems to be facilitated by the levels of corruption ${ }^{8}$ and disregard for the rule of law. For example, Mexico has created 11 billionaires and the richest man on the planet, Carlos Slim, with a fortune of $\$ 84.3$ billion (FORBES, 2014), and this country recorded 34 out of 100 points of transparency; meanwhile Brazil has generated 79 billionaires, achieving 42 out 100 points in transparency. Therefore, it seems that Mexican and Brazilian billionaires have amassed tens of billions in short periods of time, which could feed enough resentment to spark social revolts and increase the levels of social violence and criminality.

Further, Brazil and Mexico come from a colonial past that has nourished social inequality for many centuries. Brazil is a country where there exists a huge difference between the rich and the poor. According to the OECD, coefficient Gini ${ }^{9}$, Brazil reaches 55 and Mexico 47 out of 100, where 0 represents perfect equality and 100 implies perfect inequality (OECD, 2014b). In this scenario, the inequality levels are still quite present in those countries, despite the prosperity of their economies and the generation of billionaires.

Another consequence of the inequality prevailing in the emerging markets, particularly in Brazil and Mexico, is the capacity of the political and economic elites

\footnotetext{
${ }^{8}$ The term corruption is taken as the abuse of public power for private purposes. This definition assumes the distinction between public and private roles. In many societies is not very clear the frontier between both spheres, and it seems to be natural to give some gifts in exchange of assigning contracts, jobs and services. The distinction between public and private spheres seems to be strange and not clearly defined. However, in developed societies the difference between the two spaces is more pronounced (ROSE-ACKERMAN, 1991)

${ }^{9}$ The Gini coefficient also known as the Gini index or Gini ratio is a measure of statistical dispersion, which represents the income distribution of a nation's residents. The Gini coefficient varies between 0 and 1 , where 0 corresponds with perfect equality (where everyone has the same or almost the same income) and 1 corresponds with perfect inequality (where, for example, one person has all the income - and everyone else has zero income) (WORLD BANK, 2014a).
} 
to transfer their assets and buy properties on abroad, mainly in the rich traditional countries such as the United States, Canada, France, Spain and the United Kingdom as a way to ensure the value of their money, perhaps due to the political and social stability that some developed countries enjoy, in contrast, to these new emerging countries, where a few families have control of the State, and the levels of criminality and violence flourish. Strong demand from wealthy cash-rich buyers from overseas is not a surprise, but rather an example of how valuable and important it is to have a place where it is possible to enjoy social and political stability, along with civil and human rights.

Everybody wants to live in a place where there is no violence and where everybody has the same civil and human rights, with the opportunity to express opinions through democratic elections, and where the rule of law is the common denominator for all citizens. However, this is not always the case in many emerging countries, where powerful families, groups or oligopolies have not only the control of the economy and finances, but also the control of the directions of the public polices and the welfare of their countries.

For example, Mexico has produced high levels of inequality with high levels of wealth concentration: indeed the entrenched power and wealth of its elite are major impediments to equality and transparency. Mexican corporations are taking an even larger share of the Mexican pie - about 25 percent of GDP, while in the U.S, corporations profits get about 12 percent of GDP, which indicates that many services, phones, soft drinks and other products cost more in Mexico than in the United states, where per capita income is five times higher than in Mexico (SHARMA, 2012).

In this context, in some emerging countries, particularly in Mexico and Brazil, there are rules by law, rather than the rule of law. In other words, instead of a creative and innovative process of court-administered laws that change continuously to reflect changing political and social values, change grows not out of the legal system but only as a result of government edict. Such a situation tends to lead to ambiguity, unpredictability, protection of private interests, and corruption (MAGNUS, 2011). It is easy to say Mexico and Brazil have some predisposition for corruption and lack of transparency, but there is an asymmetry between the responsibilities and profits of the fruits of corruption. Certainly, those who are more powerful are less likely to be accountable and go away in impunity than those who do not have any power in society. Ultimately, the rule of law is the only source of 
equilibrium and balance to create strong nations and sustainable growth in the long run.

For Niall Ferguson, the success of the West and developed countries is due to a set of elements among which the rule of law takes an important place as a way to establish social stability and government with legitimacy. "The rule of law as a means of protecting private owners and peacefully resolving disputes between them, which formed the basis for the most stable form of representative government" (FERGUSON, 2011).

Ferguson also affirms that the rule of law is a pillar to ensure property rights, and it was the principle for the economic development in the Anglo-Saxon world: "the rule of law and representative government, in that an optimal system of social and political order emerged in the English-speaking world, based on private property rights and the representation of property-owners in elected legislatures" (FERGUSON, 2011).

It is not an accident that economic development is marked by the development of judiciary institutions. It is essential to have an independent judiciary, and judge-made law, providing for rules that are clearly understood, and that can be enforced or challenged. That, at least, is the fundamental belief in Western societies that insist that contract law, property rights and neutral third party enforcement contribute to accountability, political stability, regulatory quality and the control of corruption (MAGNUS, 2011). In countries where legality is marginal, the extra-legal world is the norm, opportunities for corruption and impunity are higher, and the consequences which are more severe for the most vulnerable in society, which cause delays in improving social conditions and reducing inequalities.

For Richard Wilkinson and Kate Pickett, inequality does not harm only the poor, but also the middle and upper classes. For these authors, there is a correlation between poverty and criminality, fear, violence and health problems, which will damage the wellbeing, not only of the poor, but also the rich, as they cannot walk free on the streets without fear of being attacked. The rich also develop more paranoia, stress, mistrust, and mental health problems (WILKINSON and PICKETT, 2010). 


\section{Conclusions}

Enforcing the rule of law is a challenge for reformers and political elites. This is the moment to uproot the illusion that helping the poor is just for the benefit for the poor. It is not only about that bridging the gap between classes, it is also about a generally more healthy form of social good. This kind of legal integration can help almost all groups of a country. On one hand, reformers collected facts and numbers to win the support of the poor, through elections, and on the other hand, the elites must support reform not only for patriotism or altruism, but because the change will enlarge their wallets and wellbeing will be for all sectors of the country (DE SOTO, 2001). For example, if the extra-legal sector is more expensive, it will be less interesting, and playing by the rules of transparency will be more profitable. Such a shift will open up, let's say, the opportunity to create massive low-cost housing programs for the poor with homes that will not only be better built, but rather much cheaper than if they themselves build under the extra-legal sector (DE SOTO, 2001).

Mexico and Brazil have an excellent opportunity to improve their social conditions and enforce the rule of law because their economies are flourishing. For example, Brazil has the potential to be much bigger with the capacity to become an economy close to $\$ 10$ trillion, about five times bigger than it is today. Brazil is now home to giant companies such as PETRONAS, which in September 2010 launched the world's largest share offering, of $\$ 67$ billion, to fund exploitation of some of the world's largest oil reserves. However, the country still needs reforms in areas ranging from taxation to infrastructure. Brazilian democracy will require large-scale new programs to improve the quality of health care and education, and increase the use of technology (O’NEILL 2011).

On the other hand, Mexico has all conditions to increase their economic growth, as China is no longer as cheap as it used to be. According to HSBC bank, in 2000 it cost just $\$ 0.32$ dollar an hour to employ a Chinese factory worker, against $\$ 1.51$ dollar for a Mexican one. By 2011 Chinese wages had quintupled to $\$ 1.63$ dollar, whereas Mexican ones had risen only to $\$ 2.10$ dollar, therefore the minimum wage in Shanghai and Qingdao is now higher than in Mexico City and Monterrey. Besides, Mexico is closer to the biggest market of the world -The United States of America- than any other emerging market (THE ECONOMIST, 2012). Furthermore, many companies they are moving or setting up offices in Mexico, for example, Siemens -a German multinational- employs 6,000 people at 13 factories and 3 research centers in that country. 
Certainly, Mexico and Brazil have huge challenges in terms of reducing poverty in "Ciudad perdidas" or "Favelas", and diminishing the levels of corruption, murders, drug trafficking, human trafficking, child exploitation, violence related to gangs and drugs, child and women prostitution, infrastructure improvement, and expansion of public health and education facilities. Mexico and Brazil are in a key moment to accomplish a project of development and they are generating the resources for doing that. Nevertheless, to make the levels of progress discussed herein they must prove their political will, engage their economic and financial elites, and promote social compromise, a real project of democracy, where the rule of law becomes the rule, coupled of course, with serious tax reforms and efficient governance. The rule of law is a condition not only for improving the quality of governance ${ }^{10}$, but also setting the basis of the sustainable development ${ }^{11}$ in the long term, and the wellbeing of the citizens to face the future.

The new global reality imposes new challenges for emerging countries, mainly for Brazil and Mexico, which means not only to be focused on economic growth, but also improving civil and property rights, and reducing high levels of endemic corruption and impunity in nations. To create, enhance and respect the rule of law is extremely important in order to build a model of sustainable development to long term, otherwise emerging countries run the risk of experiencing a historically brief momentum in the 21 st century.

We are witnessing a new stage in history, not only concerning the rise of the emerging countries, particularly in Latin America, and the weakness of the West, but also the importance of the rule of law as a means to establish social, political, economic, and cultural harmony in the new global order. The emerging countries, mainly Brazil and Mexico have an excellent opportunity in the near future. Implementing and respecting the rule of law will be the decisive point to determine the future these countries and the human and civil rights of their citizens.

\footnotetext{
${ }^{10}$ The term governance is used according to the World Bank: "We define governance broadly as the traditions and institutions by which authority in a country is exercised. This includes the process by which governments are selected, monitored and replaced; the capacity of the government to effectively formulate and implement sound policies; and the respect of citizens and the state for the institutions that govern economic and social interactions among them" (KAUFMANN et al., 2009, p. 5).

11 Sustainable development is the development that meets the needs of the present without compromising the ability of future generations to meet their own needs (STRANGE and BAYLEY, 2008).
} 
Nubia Nieto é PhD. em geopolitica na Universidade PantheonSorbonne Paris I e Pesquisadora independente. E-mail: continents.sky@gmail.com.

\section{Bibliography}

BBC. The Mint countries: Next economic giants?. BBC. 2014. Disponível em: <http://www.bbc.co.uk/news/magazine-25548060>. Acesso em: 10 set. 2017.

BEN, Jacobs; RUSCHE, Dominic; AGREEN, David. Trump-Mexico relations hit new low after 20\% border wall tax mooted. The guardian. Reino Unido. 2017.

DE SOTO, Hernando. The mystery of capital: Why capitalism triumphs in the west and fails everywhere else. Reino Unido: Black Swan, 2001.

FERGUSON, Niall. Civilization. The West and the Rest. London: Allen Lane-Penguin Books, 2011.

FORBES. The World's billionaires 2011”. New York, US: Forbes Magazine, 2011. Disponível em: <http://www.forbes.com/lists/2011/10/billionaires_2011.html Retrieved>. Acesso em: 7 fev. 2013.

FORBES. The list of Mexican billionaires based on an annual assessment of wealth and assets. Forbes magazine. Nova York. 10 mar. 2012a.

FORBES. The list of Brazilian billionaires based on an annual assessment of wealth and assets. Forbes magazine. Nova York. dez. 2012b.

FORBES. The World's billionaires 2014. Today's Winners \& Losers. Forbes magazine. Nova York. 2014. Disponível em: <http:/www.forbes.com/billionaires/list/\#tab:overall>. Acesso em: 9 set. 2014.

GOLDMAN SACHS. Dreaming with Brics: The Path to 2050. Nova York: Goldman Sachs, Global Economics Paper, n. 99, 2003.

GRIFFIS, Michael. Economic Indicators. The United States: John Wiley \& Sons, Inc, 2011.

HAJNAL, Peter; MEIKLE, Sian. The G7/G8 System: evolution, role and documentation. Reino Unido: Ashgate, 1999.

HSBC. Emerging Markets Index Q4 2012. Londres: Press Release. 2013.

INTERNATIONAL MONETARY FUND (IMF). World Economic Outlook. Washington: IMF. 2014.

KHANNA, Parag. The Second world. Reino Unido: Penguin. 2009.

KAUFMANN, Daniel; KRAY, Aart; MASTRUZZI, Massimo. Governance Matters VIIl. Agregate and Individual Governance Indicators 1996-2008. Washington: The World Bank, Policy Research Working Paper, n. 4978, 2009.

MAGNUS, George. Uprising. Will emerging markets shape or shake the world economy? Reino Unido: John Wiley. 2011. 
24 | Nubia Nieto

O'NEILL, Jim . The Growth Map. Economic Opportunity in the BRICs and Beyond. Londres: Portfolio Penguin, 2011.

ORGANISATION FOR ECONOMIC CO-OPERATION AND DEVELOPMENT (OECD). Factbook 2014: Economic, Environmental and social statistics. Paris: OECD. $2014 \mathrm{a}$.

ORGANISATION FOR ECONOMIC CO-OPERATION AND DEVELOPMENT (OECD). Society at a Glance 2014. OECD Social Indicators. Income inequality. Paris: OECD. 2014b.

UNITED NATIONS (UN). GDP and its breakdown at current prices in US Dollar. Nova York: United Nations Statistics Division/ United Nations Department of Economic and Social Affairs (DESA), 2013.

UNITED NATIONS (UN). El Estado de derecho y la justicia de transición en las sociedades que sufren o han sufrido conflictos. Informe do Secretário Geral. 2004.

ROSE-ACKERMAN, Susan. Corruption and Government: Causes, Consequences and Reform. Cambridge: Cambridge University Press. 1999.

SHARMA, Ruchir. Breakout Nations. Search of the Next Economic Miracle. Londres: Allen LanePenguin. 2012.

STRANGE, Tracey; BAYLEY, Anne. Sustainable Development. Linking economy, Society, environment. Paris: OCDE. 2008.

SOUTHWOOD, Ben. Mexico and Indonesia to eclipse UK's GDP by 2050, London: The City A.M, n. 1.798 , jan. 2013.

TRANSPARENCY INTERNATIONAL (TI). Corruption perceptions index (CPI) 2016. Berlim: Transparency International Secretariat. 2016.

THE WORLD BANK. The World Development Indicators: Distribution of income or consumption. Washington: The World Bank. 2014a.

THE WORLD BANK. The World Development Report 2014. Washington: The World Bank. $2014 \mathrm{~b}$.

THE WORLD BANK. Who catches a cold when emerging markets sneeze? Chapter 3, in Global economic prospects, p.179-215, 2016.

THE ECONOMIST. Going up in the world. Special Report. The Economist. Mexico, p. 1-16. 24, nov. 2012.

WILKINSON, Richard; PICKETT, Kate. The spirit level: Why equality is better for everyone. Londres: Penguin. 2010.

Texto recebido em 15 de março de 2017. Aprovado em 27 de março de 2017. 